\title{
Diet of harbour seals in a salmon estuary in North-West Iceland
}

\author{
Sandra M. Granquist ${ }^{1,2}$ and Erlingur Hauksson ${ }^{3}$ \\ ${ }^{\prime}$ Marine and Freshwater Research Institute, Skúlagata 4, 121 Reykjavík \\ ${ }^{2}$ The Icelandic Seal Center, Brekkugata 2, 530 Hvammstangi, Iceland \\ sandra@veidimal.is (corresponding author) \\ ${ }^{3}$ Vör Marine Research Center at Breidafjördur, Nordurtangi 3, 355 Olafsvik. erlingurhauks@outlook.com
}

\begin{abstract}
The effect of harbour seal predation on salmonids has been frequently debated, although interactions between these species have never been thoroughly investigated in Icelandic waters prior to this study. We investigated the diet of harbour seals in a salmon estuary in NW Iceland between 2009 and 2011, using hard part analysis from collected faeces. No evidence of seal predation on salmonids was found in the study. The reconstructed weight and estimated energy content of prey species showed that flatfish was the most important species group, followed by Ammodytidae. The species group found in the highest proportion of samples during the three years combined was also Ammodytidae (45\% of the samples). Ammodytidae, flatfishes and capelin dominated by numerical occurrences. However, inter- and intra-annual variation was found regarding the diet.
\end{abstract}

\section{YFIRLIT}

Fceðuval landsela i ósum lax og silungsveiðiáa i Húnapingi vestra, metin útfrá fceðuleifum i selasaur

Áhrif afráns sela á laxfiska hefur verið umdeilt, og sjaldan rannsakað við íslenskar aðstæður. Við rannsökuðum fæðuval landsela á ósasvæði á Norðurlandi vestra árin 2009 til 2011 með kvarna- og beinagreiningu úr selasaursýnum. Við fundum engar vísbendingar um laxfiska í saursýnunum. Áætluð pyngd og orkuinnihald bráđtegunda leiddu í ljós að flatfiskar voru mikilvægastir í fæðu selanna, en næstmikilvægast var síli (Ammodytidae). Síli var einnig fæðutegundin sem fannst hlutfallslega mest í saurnum öll árin (45\% sýna) og síli, flatfiskar og loðna voru ríkjandi hvað varðar fjöldi einstakra fiska. Breytileiki var pó nokkur á milli ára og einnig var árstíðabundin breytileiki í fæðuvali selanna.

Keywords: hard-part analysis, seal-feaces, otolith, seal, salmon

\section{INTRODUCTION}

The importance of salmonids in the diet of pinnipeds has been frequently debated, not the least due to the commercial value that salmonid species often have for stakeholders (Middlemas et al. 2006, Graham 2015). Since harbour seals (Phoca vitulina) are abundant in many areas where salmonid angling or salmon aquaculture is economically important harbour seals are sometimes hunted or harassed in river mouths or in the vicinity of aqua culture pens. Seal hunting in river mouths is often promoted by the interest of angling associations, but there is scarce scientific proof of a negative correlation between the number of harbour seals in the river mouth and the salmonid harvest by humans in rivers (Thompson et al. 2007, Graham 2015). This underlines the importance of increasing the knowledge of seal and salmonid interactions in river mouths.

Harbour seal feeding habits have been 
explored in previous studies and have been found to depend on prey abundance and time of year (e.g. Härkönen 1987, Härkönen \& HeideJörgensen 1991). Due to the opportunistic nature of harbour seal foraging strategy, they are likely to prey on salmonids to some extent in areas where salmonids are abundant (e.g. Roffe \& Mate 1984, Zamon 2001, Middlemas et al. 2006). As an example, Middlemas et al. (2006) found an aggregative response among harbour seals to the abundance of returning salmon, and further, a type 3 functional response was found regarding harbour seal predation on salmonids. Apart from direct predation, several studies have described indirect effects on salmonid populations due to seal abundance, such as spread of nematodes from seals to salmonids (Hauksson 1990) and wounds from seal claws and teeth may be observed on caught fish (Harmon et al. 1994, Fryer 1998, Thompson \& Mackay 1999, Granquist 2014). Seal-induced injuries have in some studies been found to damage the fillets, which affects human harvesting, and ultimately such injuries may increase the mortality risk among salmonids (Harmon et al. 1994, Naughton et al. 2011). However, several studies have on the contrary suggested that salmonids are not a common prey for harbour seals and that harbour seal predation is not likely to have a severe effect on salmonid stocks (e.g. Roffe \& Mate 1984, Carter et al. 2001, Middlemas et al. 2006, Matejusová et al. 2008).

The Icelandic angling industry consists of Atlantic salmon (Salmo salar), brown trout (Salmo trutta) and arctic char (Salvelinus alpinus) and is economically important in many rural areas of the country (Toivonen et al. 2004). In Iceland, salmon fishing in the sea is illegal, and salmon is mainly caught in rivers by angling, with a few exceptions (e.g. ÖlfusáHvítá, Thjórsá, Skaftá, Skjálfandafljót and Hvítá in Borgarfjördur) where nets are used to catch salmon in rivers (Gudbergsson 2015). Arctic char and brown trout may be caught in nets in lagoons or by river angling. The fisheries are managed by angling associations consisting of the local landowners in every river area and the fishing right is rented to entrepreneurs who in turn sell permissions to sport anglers (Gudbergsson 2015). The estuaries of some of the most important salmon rivers in Iceland are inhabited by harbour seals and aggregations of up to 400 seals have been observed in the biggest estuary haul-out site (Granquist \& Hauksson, 2016).

Recent studies indicated a severe decrease in the Icelandic harbour seal population during the last decade (Hauksson 2010, Granquist et al. 2011, Granquist et al. 2015) and the reason for the decline is unknown. The lack of ordinance to report hunted seals to the authorities in Iceland, along with insufficient reports of seals as by-catch has resulted in inadequate numbers of total removals (NAMMCO Annual Report 2014). The importance of using seal meat and skin has decreased recently and seal hunting for this purpose has become negligible. Instead the greater part of the harbour seal hunt occurs around river mouths with the purpose of reducing the potential impact of harbour seals on the salmonid stocks.

The diet of the Icelandic harbour seal population has previously been investigated using hard part analysis (otoliths and bones) from seal stomachs and faeces content (Eldon 1977 cited in Bogason 1995, Hauksson \& Bogason 1997, Nebel 2011). These studies indicate that harbour seals mainly feed on cod (Gadus morhua), but also on Ammodytes sp., redfish (Sebasets sp.), saithe (Pollachius virens), herring (Clupea harrengus) and catfish (Anarhichas lupus). However, the diet of seals hauling out in salmon estuaries has never been thoroughly investigated in Icelandic waters prior to this study. Since some previous studies from other areas have suggested that individual seals might specialize in salmonids (Thórisson $\&$ Sturlaugsson 1995), further research on the topic is required.

The aim of the present study was to investigate the diet of harbour seals hauling out in a salmon and trout river estuary, especially considering the importance of salmon, brown trout and Arctic char in the seal diet. Since salmon and trout angling in Icelandic rivers 
is economically significant, it is important to investigate the foraging pattern of harbour seals hauling out in estuaries. Such research is important in light of the seal culling occurring in estuaries, which might be contributing to the observed decrease in the Icelandic harbour seal population (Thompson et al. 2007). The results of this study therefore have an important directly applicable value for sustainable harbour seal and salmonid management actions in Iceland.

\section{MATERIALS AND METHODS}

\section{The study area}

The study was conducted between May and September of 2009-2011 in the estuary area of Osar and Bjargaos, Hunafjordur, NW Iceland. Bjargaos is the estuary of three major salmon angling rivers; Vididalsa, Fitja and Gljufura where Atlantic salmon, Arctic char and brown trout are abundant. The Osar estuary, which is Sigridarstadavatn lagoon's outlet to the sea, is located approximately $1.5 \mathrm{~km}$ west of Bjargaos. The beaches in these estuaries are sandy. Osar is an important breeding and haul-out site for harbour seals and previous studies have shown a bimodal haul-out distribution in this area, with one peak during the pupping season in June and the next during the molting season in August (Granquist \& Hauksson, 2016). The number of seals in Bjargaos peaks between the two haul-out peaks at Osar, indicating that the seals use Bjargaos as a foraging site. The monthly average number of hauling-out seals during the time of the present study ranged from 108.6 $(\mathrm{SD}=86.6)$ to $251.3(\mathrm{SD}=79.6)$ in Osar and 0 to $34.0(\mathrm{SD}=36.7)$ in Bjargaos (Granquist \& Hauksson, 2016).

\section{Sampling and analyzing faeces}

Faeces samples were collected during low tide at every spring tide throughout the study period. All observed faeces samples in the haul-out site during each visit were collected and put into separate plastic bags and kept in a freezer at $-20{ }^{\circ} \mathrm{C}$ until further analysis. A total of 253 seal faeces samples were collected $\left(\mathrm{n}_{2009}=42, \mathrm{n}_{2010=} 86\right.$ and $\mathrm{n}_{2011}=125$ ).

Samples were taken from the freezer 24 hours before the analysis, put into a warm waterbath containing detergent and kept overnight to dissolve fats and lipids from the otoliths and fish bones. Each sample was then carefully washed through a sieve with $250 \mu \mathrm{m}$ mesh size using warm water. Otoliths, fish bones and invertebrate rests (i.e. bivalves, cephalopods and gastropods) were collected for the diet analyses, with the exception of 2009 when only otoliths were collected. Therefore, otoliths formed the basis for the diet analyses and fish bones and invertebrates were used for secondary information in 2010 and 2011. In samples where no otoliths but some fish bones were found, fish bones were used to identify the fish species, or species group, that had been eaten. This was found to be particularly important regarding catfish, skate (ray) and lumpsucker (Cyclopterus lumpus).

\section{Analysis of prey data}

The diet of harbour seals was analysed using four aspects: 1) Frequency of occurrence of each prey species expressed as the proportion of examined faeces samples that contained the different prey species, 2) Numerical occurrence of individuals of each prey species for all faeces samples in total, 3) Reconstructed weight values of prey species expressed as proportions of weight, and 4) Proportional energy content of the different prey species calculated from reconstructed weight and the appropriate energy density factor (see Windell 1971).

Otoliths were identified to fish species if possible. In some cases, the otoliths were degraded to the extent that they could not be identified to species and in such cases family or species group was recorded (Härkönen 1986, Svetocheva et al. 2007). Sagittae otoliths were primarily used, although Asteriiscii and Lapilli otoliths from gadoids were also found. Sagittae otoliths were identified as right or left hand otoliths if possible and either the right or left otolith was chosen randomly and the length was measured. Unmatched otoliths were counted as single prey. Due to the potential risk of otoliths being completely digested, the number of otoliths found in the faeces was considered as 
minimun (Bowen 2000). However, we did not correct for this in our analyses.

The length of the otoliths was measured in a stereoscope with graded ocular. In samples including many otoliths from the same species, the otoliths were laid out in an orderly way on a blue piece of cardboard, forming the images' background and put under the stereoscope at $7 \times 1$ magnification. A photo was then taken through the lens by a digital camera (Infinity1 Microscopy Cameras, Lumenera Corporation) using the applied INFINITY Software v: 5.0.3 for Windows XP. Capture resolution was $2048 \times 1536$, brightness of target 224 and AEC selected. Gain(x) was set equal to 1.76 and no overlay bitmap selected. The digital photos were analysed with SigmaScan ${ }^{\circledR}$ Pro 5.0 for Windows ${ }^{\circledR}$ 95, 98 and NT which measured the maximum diameter and the diameter perpendicular to it for each individual otolith. By using a plastic square of known size $(2.3 \times 2.2 \times 1$ $\mathrm{mm})$ as reference the diameters from the image analyses were converted to $\mathrm{mm}$.

The ratio between measurements made with the stereoscope and the digital image analysis was calculated to ensure comparability between the methods. This ratio was close to 1 for all species, except for Ammodytes sp. and capelin (Mallotus villosus), where a conversion factor (CF) was applied to correct for this potential bias (Ammodytes sp.; $\mathrm{CF}=1.118, \mathrm{SE}=0.017$, $\mathrm{CI}=0.003, \mathrm{n}=160$ and capelin; $\mathrm{CF}=1.595$, $\mathrm{SE}=0.037, \mathrm{CI}=0.071, \mathrm{n}=72$ ).

The degree of degradation of the otoliths was defined on a scale between 1 and 4 depending on morphological features (Grellier \& Hammond 2006). Grade-specific digestion coefficients $\left(d_{e}\right)$ estimated for grey seals and provided in Grellier \& Hammond (2006) was then used to correct for digestion. Otolith size was back-calculated into fish length and fish weight by using relationships derived from unpublished data from Hauksson \& Bogason (1997) and from Härkönen (1986) (see Supplement Table S1). The energy content of the fish was determined by multiplying fish weight by the species specific energy-density derived from Ólafsdóttir \& Hauksson (2005).
Statistical analyses

Comparisons were made between methods of measuring length of otoliths as described in Bland \& Altman (1986). Frequency of occurrence and numerical occurrence of prey species were tested in relation to sampling months and years, using Pearson's $\chi^{2}$ test of independence with Yate's correction. Statistical analyses were performed in R (R Development Core Team 2009).

Due to the highly unbalanced and non-normal nature of the data, statistical analysis was rather difficult. Therefore, a 5\% significance level was considered as only marginally significant.

\section{RESULTS}

Frequency of occurrence of prey species in faeces

Eleven $(4.3 \%)$ of the faeces samples contained no identifiable prey remains and the average number of species or species groups in every sample was $2.0(\mathrm{SD}=1.06)$.

A total of 39 prey species were identified of which 29 were fish and 10 invertebrate taxa and most species were very rarely found in the faeces. Ammodytidae occurred in most faeces samples $(45 \%)$ when the three years were combined. The occurrence of Ammodytidae, capelin, catfish, flatfish and herring in faeces was significantly different between the collection years. Ammodytidae was found in $55 \%$ of the feces in 2011, but was less frequent in the two years before. In 2009 flatfish was the species group found in most samples $(64 \%)$ and both flatfish and herring were more frequent in 2009 than in the later years. Capelin was significantly more common in 2010 (25\%) compared with 2009 and 2011. Catfish were not found in any faeces samples collected in 2009, but did occur in $11 \%$ of the samples in 2010 . Other fish and invertebrate prey items were not found to be significantly different between years (Table 1).

\section{Numerical occurrence of prey species}

In total, Ammodytidae ( $\mathrm{n}=1473)$, flatfish $(\mathrm{n}=520)$ and capelin $(\mathrm{n}=423)$ were numerically dominant in the faeces samples although occurrence significantly depended on years and 
Table 1. The number of faeces containing each species for the years of the study and the proportion of all samples that contained the species. Comparison of occurrence of food groups between years $\left(\chi^{2}-\right.$ test $(\mathrm{df}=2)$.

\begin{tabular}{|c|c|c|c|c|c|c|c|c|c|}
\hline \multirow[b]{2}{*}{$\begin{array}{l}\text { Species/ } \\
\text { species groups }\end{array}$} & \multicolumn{2}{|c|}{2009} & \multicolumn{2}{|c|}{2010} & \multicolumn{2}{|c|}{2011} & \multicolumn{2}{|c|}{$2009-2011$} & \multirow[b]{2}{*}{$\chi^{2}(p)$} \\
\hline & $\begin{array}{c}\text { Number } \\
\text { of } \\
\text { samples }\end{array}$ & $\%$ & $\begin{array}{c}\text { Number } \\
\text { of } \\
\text { samples }\end{array}$ & $\%$ & $\begin{array}{c}\text { Number } \\
\text { of } \\
\text { samples }\end{array}$ & $\%$ & $\begin{array}{c}\text { Number } \\
\text { of } \\
\text { samples }\end{array}$ & $\%$ & \\
\hline Ammodytidae & 18 & 42.9 & 25 & 31.2 & 66 & 55.0 & 109 & 45.0 & $11.04(0.004)$ \\
\hline Mallotus villosus & 6 & 14.3 & 20 & 25.0 & 11 & 9.2 & 37 & 15.3 & $9.33(0.01)$ \\
\hline Anarhichas lupus & 0 & 0.0 & 9 & 11.2 & 5 & 4.2 & 14 & 5.8 & $7.54(0.02)^{1}$ \\
\hline Flatfish & 27 & 64.3 & 19 & 23.8 & 19 & 15.8 & 65 & 26.9 & $37.77(<0.001)$ \\
\hline Gadoids & 12 & 28.6 & 23 & 28.8 & 20 & 16.7 & 55 & 22.7 & $4.98(0.08)$ \\
\hline Clupea harengus & 15 & 35.7 & 1 & 1.2 & 7 & 5.8 & 23 & 9.5 & $41.76(<0.001)^{1}$ \\
\hline Invertebrates $^{2}$ & - & - & 52 & 65.0 & 38 & 31.7 & - & - & - \\
\hline Cyclopterus lumpus & 0 & 0.0 & 1 & 1.2 & 4 & 3.3 & 5 & 2.1 & $2.10(0.35)^{1}$ \\
\hline Sebastes sp. & 0 & 0.0 & 0 & 0.0 & 1 & 0.1 & 1 & 0.4 & - \\
\hline Skate & 0 & 0.0 & 1 & 1.2 & 0 & 0.0 & 1 & 0.4 & - \\
\hline $\begin{array}{l}\text { Unidentified \& } \\
\text { other fish }\end{array}$ & - & - & 27 & 33.8 & 39 & 32.5 & - & - & - \\
\hline
\end{tabular}

${ }^{1} \chi^{2}$ approximation may be incorrect due to low frequency

${ }^{2}$ Invertebrate remains not collected from faeces samples in year 2009

${ }^{3}$ Remains of unidentifiable fish not collected in 2009

months of collection (Supplement Table S2). Ammodytidae occurred more frequently in 2011 than in 2009 and 2010. Capelin occurred more frequently by numbers in 2010 compared with the other years, but flatfishes and herring were more common in 2009 compared to 2010 and 2011. The numerical occurrence of gadoids was more evenly found during the sampling periods of the three years (4-5.4\%) (Figure 1,
Supplement Table S2).

On average for all years included in the study, Ammodytidae was the prey group with the highest numerical occurrence between May (data only collected in 2011) and July (between $51 \%$ and $72 \%$ of all recovered otoliths), while flatfishes were the most common species group in August and September (43 and $45 \%$ of all found otoliths). For May, only samples from

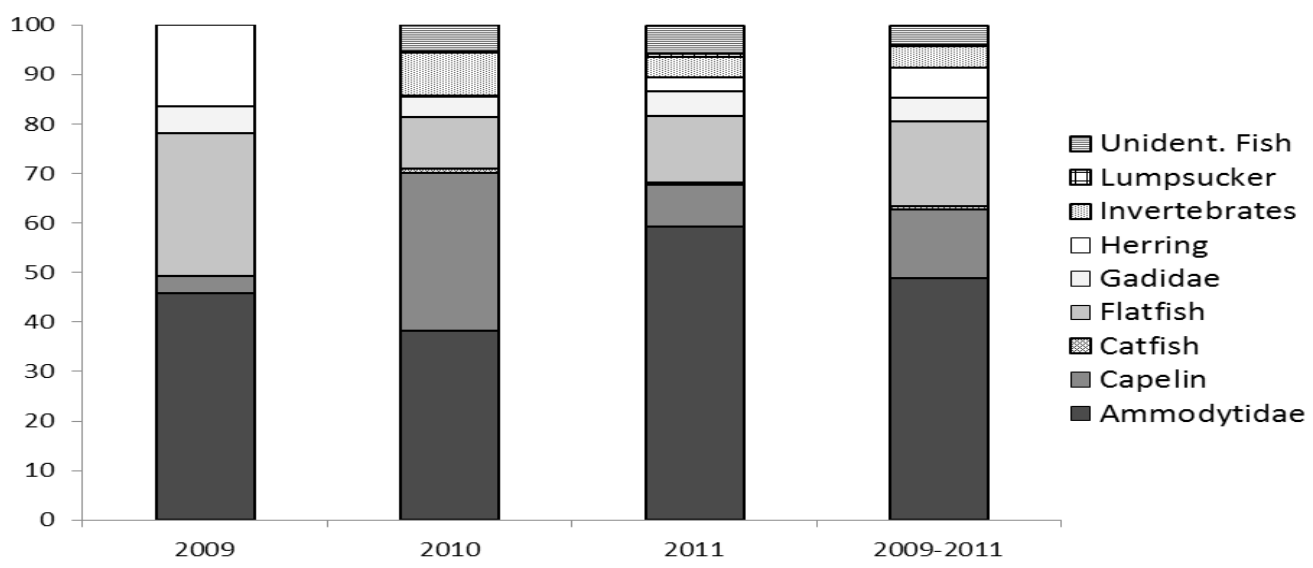

Figure 1: Estimated proportion of occurrence by number for the different prey species in total for each year. 
Table 2. Average size of reconstructed prey length $(\mathrm{cm})$, with minimum and maximum and inter-quartile range (IQR).

\begin{tabular}{lccccccc}
\hline Species and groups & Mean & Minimum & IQR (25\%) & Median & IQR (75\%) & Maximum & N \\
\hline Anarhichas lupus & 41.0 & 41.0 & 41.0 & 41.0 & 41.0 & 41.0 & 1 \\
Hippoglossoides platessoides & 35.7 & 26.1 & 33.9 & 36.0 & 37.5 & 44.0 & 40 \\
Limanda limanda $_{\text {Ammodytes }}^{1}$ & 25.4 & 13.9 & 21.6 & 22.7 & 28,0 & 41.4 & 11 \\
Melanogrammus aeglefinus $_{\text {Clupea harengus }}$ & 25.8 & 5.8 & 20.7 & 25.9 & 30.5 & 42.5 & 1472 \\
Sebastes sp. & 15.2 & 2.4 & 10.6 & 12.9 & 19.2 & 31.8 & 19 \\
Merlangius merlangus & 18.5 & 6.1 & 16.8 & 18.4 & 20.0 & 31.6 & 183 \\
Pollachius viren & 19.4 & 17.3 & 18.4 & 19.4 & 20.5 & 21.6 & 2 \\
Gadus morhua & 11.6 & 11.6 & 11.6 & 11.6 & 11.6 & 11.6 & 1 \\
Mallotus villosus & 23.0 & 6.2 & 12.0 & 20.5 & 34.6 & 45.0 & 31 \\
\hline
\end{tabular}

${ }^{1}$ A. marinus, A. tobianus and Hyperoplus lanceolatus.

2011 were at hand and over $70 \%$ of all otoliths found during that period were Ammodytidae, with capelin in second place (23\%) (Supplement Table S2). In June of 2009 and 2011, Ammodytidae dominated in the faeces (52\% and $71 \%$ respectively), while in 2010 capelin $(65 \%)$ dominated. In July Ammodytidae dominated in numerical occurrence in all three years, the $70 \%$ observed in 2011 being significantly higher than the $53 \%$ in $2010(p<0.001)$. In August, flatfishes were dominant in 2009 and 2010 and dominant together with Ammodytidae in 2011. However, Ammodytidae were absent in faeces collected in August 2010.

In September the number of samples was limited and no significant differences could be demonstrated except for the invertebrate group, which was most prevalent in $2010(50 \%)$, and flatfishes were most frequent (45\%) in 2011 (Supplement Table S2).

\section{Prey size}

The bulk of the fish had a reconstructed standard length between 8 and $41 \mathrm{~cm}$, with the median about $20 \mathrm{~cm}$. The Ammodytes sp., the most numerous fish in the faeces, had no indication of multimodal distribution in reconstructed standard length, the median and mean being about $26 \mathrm{~cm}$. Comparable results were found in the reconstructed standard lengths of capelin, herring and long rough dab, none of which showed indications of multimodal distribution as indicated by the closeness of the median and mean lengths of each species. Other fish species occurred rarely in the samples and hence their distribution could not be analysed. The biggest fish according to reconstructed standard length was a catfish of $41 \mathrm{~cm}$ (Table 2).

\section{Proportion by weight and energy content of prey species}

The total reconstructed fish weight relative to sampling days showed a notable difference between years (Figure 2). In 2009, flatfishes were most prominent, with herring and Ammodytes sp. in second place. Flatfishes increased by weight as the season progressed. In 2010 Ammodytidae dominated by weight in the beginning of the summer, but were replaced by flatfishes later in the summer. Capelin were important in the diet on the first sampling day in 2010 (early June) and catfish was an important species on four out of the eitgh sampling days. In 2011 Ammodytidae dominated in the beginning of the summer, with flatfishes coming in second. In the latter half of the summer flatfishes increased in importance, 
2009

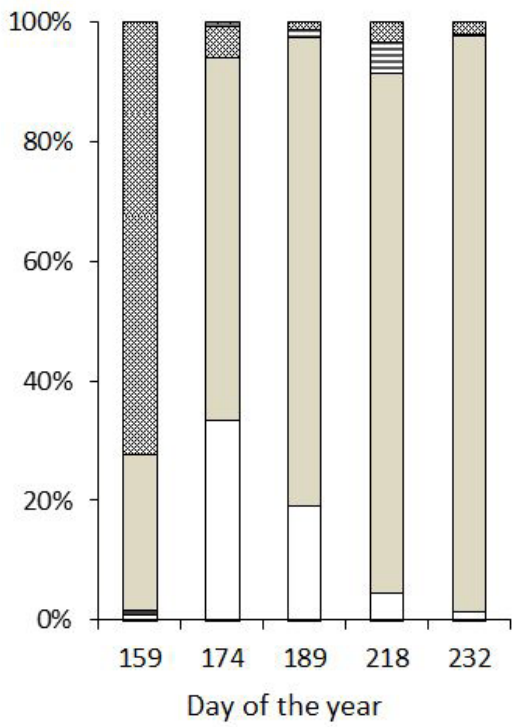

2011

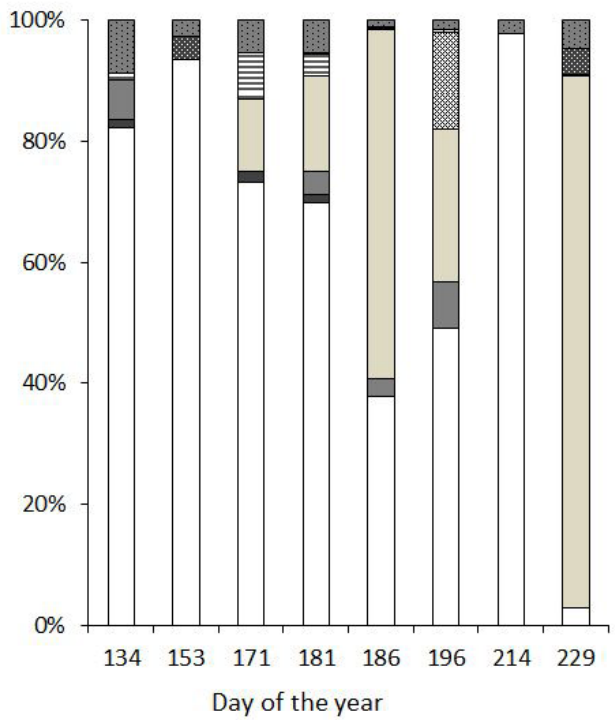

with 2nd August (day of the year: 214) as an exception (however, only corresponding to 7 samples), when the diet consisted of merely Ammodytidae (Figure 2).

Taking energy content into consideration the picture was similar, though Ammodytidae fish increased in importance compared with flatfishes and herring increased markedly in importance (Figure 3).
2010



\begin{tabular}{|c|c|c|}
\hline$\square$ Ammodytidae & Capelin & $\square$ Catfish \\
\hline$\square$ Flatfish & 日Gadidae & 図Herring \\
\hline 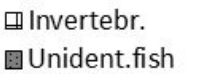 & 图 Lumpsucker & $\square$ Other fisl \\
\hline
\end{tabular}

Figure 2. Diet by weight from reconstructed fish weights from otoliths' sizes in accordance with day of the year for the years 2009, 2010 and 2011.

\section{DISCUSSION}

In this study we found no evidence of salmonid predation by harbour seals hauling out in the vicinity of the estuary leading to three major Atlantic salmon, brown trout and Arctic char rivers in NW Iceland. Some differences were found between years regarding the importance of different prey species and the period of summer affected the diet of the seals. 

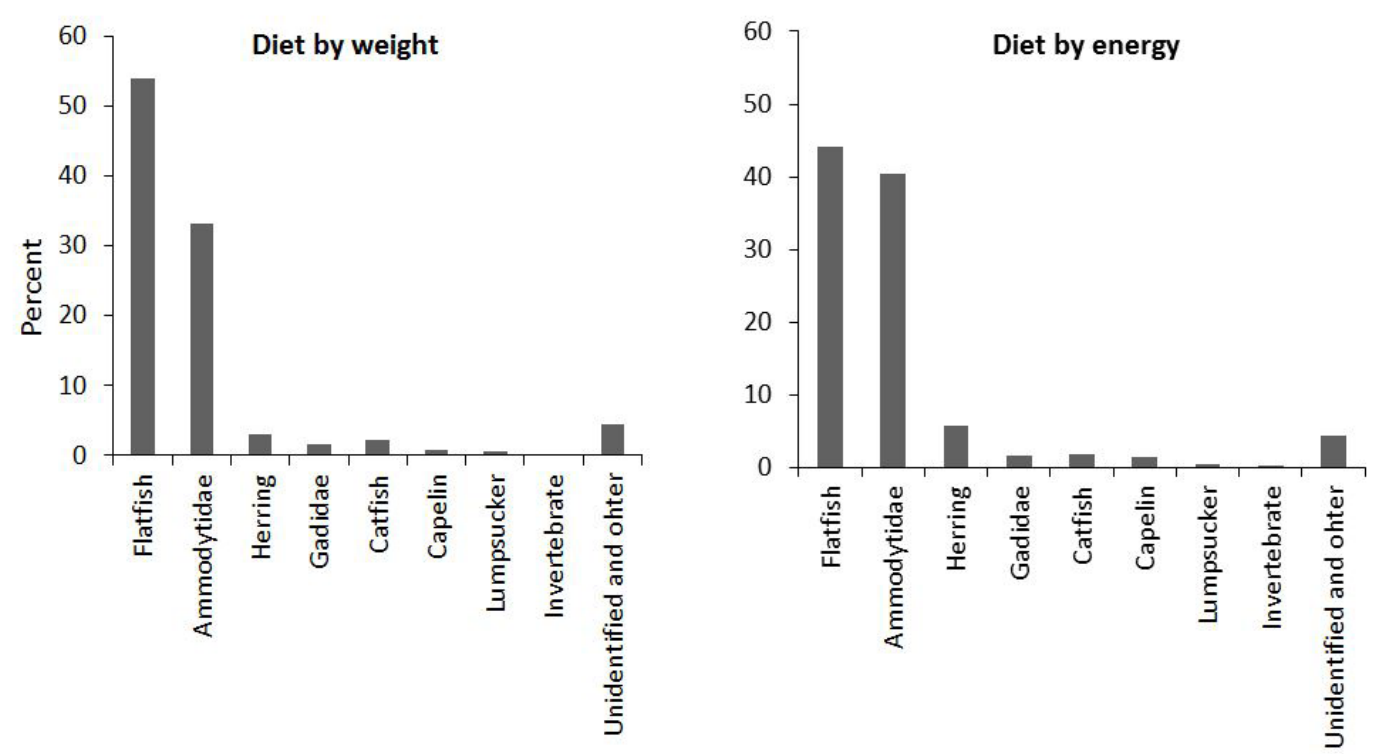

Figure 3. Overall diet in the summers of years 2009, 2010 and 2011 combined, by weight and energy for comparison.

Ammodytidae was the species group that was found in most of the samples overall (Table 1) and also usually the dominating species groups in terms of numerical occurrence Figure 3. The latter was however found to be affected by time of year. Flatfishes were the most common species group by numbers at the end of the summer (Supplement Table S2). However, prey species varied considerably in size and hence the proportional weight of each species in the diet, as well as estimated proportional energy content of each species, probably correspond best to the importance of a species in the harbour seal diet. Our results therefore show that flatfishes were the most important species group followed by Ammodytidae (Figure 3).

The diet of harbour seals in the estuary area compared to other Icelandic coastal waters

Samples were collected throughout the summer and therefore during the period of year when salmon were returning back into the rivers to spawn, as well as when smolt and adult salmon were passing the river mouth on their way out to sea. Salmon catch data showed that the abundance of salmon in the river mouth was average during the years of study (Gudbergsson 2012). However, we found no indication of salmonids being an important prey of the seals hauling out in the estuary area. Some previous studies suggest that harbour seals, in some cases, specialize in preying on trout and other freshwaters species (e.g. Hauksson 1990, Graham et al. 2011). Never the less, in agreement with the results of the present study several previous studies have found that although salmonids are present in the vicinity of harbour seal haul-outs, salmonids are not necessarily an important species in the seal diet (e.g. Roffe \& Mate 1984, Carter et al. 2001, Middlemas et al. 2006, Matejusová et al. 2008). Carter et al. (2001) found in a study in Scotland that, although harbour seals were found to prey on salmon, salmon mortality was higher due to angling than due to seal predation. In 2009 and 2010 Granquist (2014) investigated wounds due to harbour seal predation on salmonids caught in five important salmon angling rivers in NW Iceland, three of which have their inlet in the estuary area investigated in the present study. On average, $<1 \%$ of the salmon and $<0.1 \%$ of arctic char and brown trout that were caught 
during the period of study had seal induced wounds. This finding further supports the conclusion that salmon and trout are not of great importance in the diet of harbour seals in this estuary area. It has however been stated that the importance of seal-induced wounds on salmonids is both species and prey-andpredator density dependent and some studies have reported a considerably higher proportion of caught salmonid with seal induced wounds (Harmon et al. 1994, Fryer 1998, Thompson \& Mackay 1999, Naughton et al. 2011).

Flatfishes, Ammodytes, gadoids, herring, catfish and capelin, which are all abundant in Icelandic waters (Marine Research Institute 2011), were found to be important prey species in the present study. This finding is in accordance with previous harbour seal diet studies in Iceland (Hauksson \& Bogason 1997). In a study conducted in the north-western part of Icelandic waters during the period 2008 - 2011, these species and species groups were also the main prey of the 64 harbour seals sampled (Nebel 2011). This comparison suggests that harbour seals on haul-outs or pupping sites near river mouths do not differ in their diet compared to seals in other areas and implies that the seals feed outside of the estuary area. This is in agreement with a study by Hauksson (2005) which showed that harbour seals hauling out in estuaries of the fjords Hamarsfjördur and Álftafjördur in east Iceland do not solely forage in the estuary but also in the outside waters. Cod were frequently eaten by the harbour seals, although not commonly abundant in the estuary. Additionally, although the abundance of arctic char was high in the estuary area, no remains of char were found in the harbour seals' stomachs (Hauksson 2005). Previous knowledge about summer foraging and movements of harbour seals hauling out in the river-estuarine habitat at Osar and Bjargaos is lacking. A study from Scotland has reported that radio-tagged harbour seals travelled up to $45 \mathrm{~km}$ from their haul-out sites on feeding trips for up to 6 days (Thompson \& Miller 1990). Other studies indicate that harbour seals mostly forage in shallow waters, less than 50 meters in depth (Härkönen \&
Heide-Jörgensen 1991).

Our results imply that there are reasons other than foraging that leads seals to haul out in the estuary areas of Osar and Bjargaos. The most probable reason is that the topography of the area, with its long sandy beaches, is a suitable pupping and molting area. The outlet of the lagoon in Osar is used to the highest extent as a haul-out and breeding site, while the seals seldom haul out near Bjargaos (Granquist \& Hauksson, 2016).

Taking the decrease in the Icelandic $A$. marinus and A. tobianus populations (Lilliendahl et al. 2013) into consideration, it was interesting to see how frequent Ammodytes sp. fish were in the faeces samples. However, this was also observed in the NW Atlantic, where sand eels dominated in the grey seal diet around Sable Islands, Nova Scotia, despite a fisheries survey indicating a decrease in the sand eel population (Bowen \& Harrison 2006). The results from the present study indicate that the decrease in the Ammodytes populations around Iceland is not severely affecting the decrease in the harbour seal population in the north-western coastal waters.

\section{Methodological considerations}

In this study, we used the classical method of analysing otoliths, fish bones and invertebrates found in faeces samples. However, fish bones were not investigated in 2009 and therefore the data from 2009 could underestimate the importance of catfish, lumpsucker and skate. If relationships between otolith size, fish size and the energy content of the different fish species are available it could provide information about the importance of prey species in the seal diet (Härkönen 1986, Pierce \& Boyle 1991, Svetocheva et al. 2007). However, estimating the diet of pinnipeds from prey structures recovered from faeces presents a number of potential biases (Jobling 1987). The sources of possible biases are well documented in the general literature (Pierce \& Boyle 1991; Bowen $\&$ Siniff 1999), one of them being that hard parts are degraded to some extent or even totally by the digestion in the stomachs and intestines of 
the seals (e.g. Silva \& Neilson 1985, Pierce \& Boyle 1991, Bowen 2000).

Prey species differ in the extent to which they are subject to degradation effects. Complete digestion of otoliths can distort the relative importance of prey in the diet, as well as the size of prey eaten (Bowen \& Harrison 2006). Species-specific numerical correction factors (NCFs) due to complete digestion of otoliths in harbour seals would have been of special interest in this study, particularly for salmonids, for comparison with other prey found in the faeces. According to Bowen (2000) Rainbow trout (Oncorhynchus mykis) and Chinook salmon (Oncorhynchus tshawytscha) had NCFs of about 1.6 or similar to some flatfishes; on the other hand cod had an NCF of about 1.1 and sand eels $2-6$. The NCF for herring was also quite high or $1.6-3.3$. Thus, the probability of otoliths eroding completely was not considered to be higher for salmonid otoliths than for otoliths from other species such as sandeel. Since sandeel otoliths were frequently found in the samples, the absence of salmonids food remains was considered likely to have been due to lack of harbour seal predation on salmonids.

It should be underlined that despite the risk of underestimation, several studies have shown that salmonid otoliths are found using this method if they are abundant. As an example, Thórisson \& Sturlaugsson (1995) found that during salmon post smolt releases off the northern shores of Snaefellsnes, otoliths from 49 post smolt salmon were found in the 11 seal stomachs that were analysed. Hence, if salmonids had been an important prey of harbour seals in the present study it is likely that at least some salmonid otoliths or bones would have been found.

Although the method used in this study has possible drawbacks, it also has several advantages. Firstly, it requires a minimum of equipment and is hence a cheap method. Secondly, it has ethical advantages since, by using faeces, it is possible to get several samples from each individual without killing, hurting or even disturbing the seals. As a comparison, feeding analysis using stomach contents or tissue samples such as blubber, muscle or blood for stable isotope analysis or fatty acid analysis calls for either killing or severely disturbing and/or pursuing the animals during sampling.

\section{Concluding remarks}

The results of this study indicate that salmonids are probably rarely preyed upon by harbour seals, which is in agreement with other previous studies on harbour seals hauling out in estuary areas. Further investigations using alternative methods, such as stable isotope analysis and prey-DNA analysis, to investigate foraging of harbour seals hauling out in the Osar and Bjargaos estuarine system is ongoing. Combined with this present study, that research will increase the knowledge of the Icelandic harbour seal population diet further, for example regarding the importance of salmonids in the diet, and will aid in formulation of management strategies regarding harbour seals.

\section{ACKNOWLEDGEMENTS}

Thanks to Halldór Jón Pálsson, Hrafnhildur Laufey Hafsteinsdóttir, Ester Sánchez Cacho, Laila Arranda Romero, Elsa Freschet, Haraldur Fridrik Arason and Gudmundur Jóhannesson for field assistance during the project. Thanks to Gudni Gudbergsson, Sigurdur Thorisson and Jessica Aquino for valuable discussions and to Anton Galan (deceased) and Gróa Pétursdóttir, Marine Research Institute, Reykjavik, for assisting with otolith identification.

The project was supported by The Agricultural Productivity fund. 


\section{REFERENCES}

Bland J \& Altman D 1986. Statistical methods for assessing agreement between two methods of clinical measurements. The Lancet 327, 307-310. doi: http://dx.doi.org/10.1016/j.ijnurstu.2009.10.001

Bogason V 1997. Fæða landsels (Phoca vitulina) við Ísland. [Harbour seal (Phoca vitulina) predation in Iceland]. Fjölstofnarannsóknir 1992-1995. Hafrannsóknarstofnunin, Fjölrit nr. 57, 319-330 [In Icelandic]

Bowen WD 2000. Reconstruction of pinniped diets: Accounting for complete digestion of otoliths and cephalopod beaks. Canadian Journal of Fisheries and Aquatic Sciences 57, 898-905.

doi: http://dx.doi.org/10.1139/f00-032

Bowen WD \& Harrison G 2006. Seasonal and interannual variability in grey seal diets on Sable Islands, eastern Scotian Shelf. NAMMCO Scientific Publications 6, 123-134.

doi: http://dx.doi.org/10.7557/3.2728

Bowen W \& Siniff 1999. Distribution, population biology, and feeding ecology of marine mammals. In Reynolds J, Rommel S, Reynolds J \& Rommel, $\mathrm{S}$ (eds.) Biology of Marine Mammals. Smithsonian Press, Washington, pp. 423-484.

Carter TJ, Pierre GJ, Hislop JRG, Houseman JA \& Boyle PR 2001. Predation by seals on salmonids in two Scottish estuaries. Fisheries Management and Ecology 8, 207-225.

doi: http://dx.doi.org/10.1046/j.1365-2400.2001.00247.x

Eldon J 1977. Athuganir á fæðu landsels og útsels í Breiðafirði, Faxaflóa og við Pjórsárós í janúar og febrúar 1977. [Investigations of diet of harbour seals and grey seals in the fiords Breiðafjörður and Faxaflói and in the estuary of Pjórsá, in January and February 1977]. Rannsóknarstofnun fiskiðnaðarins, 11 p. See Icelandic summary in Hafrannsóknastofnunin, Fjölrit nr. 63, page 48 [In Icelandic]

Fryer JK 1998. Frequency of pinniped-caused scars and wounds on adult spring-summer chinook and stockeye salmon returning to the columbia river. North American Journal of Fisheries Management 18, 46-51.

doi: http://dx.doi.org/10.1577/15488675(1998)018<0046:FOPCSA $>2.0 . C O ; 2$

Graham IM 2015. Seal conservations and salmon fisheries in North east Scotland. In, Redpath SM,
Gutierrez R J , Wood KA \& Yong J C (eds.). Conflicts in Conservation: Navigating Towards Solutions. University Press, Cambridge, pp. 61-63. Graham IM, Harris RN, Matejusova I \& Middlemas SJ 2011. Do 'rough' seals exist? Implications for seal conservations in the UK. Animal Conservation 14, 587-598.

Granquist SM 2014. Ummerki eftir sel á veiddum laxfiskum í völdum laxveiðiám í Húnapingi vestra og Austur-Húnavatnssýslu. [Seal injuries on caught salmonids in rivers in Hunaping vestra and Austur Húnavatnssýslu]. Institute for Freshwater Fisheries, VMST/14019 12p. [In Icelandic, English abstract].

Granquist, S and Hauksson, E 2016. Seasonal, meterological, tidal and diurnal effects on haulout patterns of harbour seals (Phoca vitulina) in Iceland. Polar Biology 1-13.

doi: http://dx.doi.org/10.1007/s00300-016-1904-3

Granquist SM, Hauksson E, Árnadóttir AB, \& Kasper J 2011. Landselstalning úr lofti árið 2011. Framvinda og niðurstöður. [Aerial count of the Icelandic harbour seal population in 2011]. Institute for Freshwater Fisheries, VMST/11051. 23 p. [In Icelandic]

Granquist SM, Hauksson E \& Stefánsson T 2015. Landselatalning árið 2014 - Notkun Cessna yfirpekju flugvélar, pyrilvængju og ómannaðs loftfars (flygildi) við talningu landsela úr lofti. [Aerial counts of the Icelandic harbour seal population using Cessna airplane, helicopter and drone]. Institute for Freshwater Fisheries, VMST/15002. 29 p. [In Icelandic, English abstract].

Grellier K \& Hammond P 2006. Robust digestion and passage rate estimates for hard parts of grey seal (Halichoerus grypus) prey. Canadian Journal of Fisheries and Aquatic Sciences 63, 1982-1998. doi: http://dx.doi.org/10.1139/f06-092

Gudbergsson G 2012. Lax- og silungsveiðin 2011 [Salmon and trout angling in 2011]. Institute for Freshwater Fisheries, VMST/12032. 37 p. [In Icelandic].

Gudbergsson G 2015. Catch statistics for Atlantic salmon Arctic charr and brown trout in Icelandic rivers and lakes 2014. Institute for Freshwater Fisheries, VMST/15023. 34 p. 
Härkönen T 1986. Guide to the otoliths of the bony fishes of the northeast Atlantic. Danbiu ApS. Hellerup, Denmark. 256p.

Härkönen T 1987. Seasonal and regional variations in the feeding-habits of the harbour seal, Phoca vitulina, in the Skaggerak and the Kattegat. Journal of Zoology 213, 535-543.

doi: http://dx.doi.org/10.1111/j.1469-7998.1987. tb03724.x

Härkönen T \& Heide-Jörgensen HE 1991. The harbour seal, Phoca vitulina, as a predator in the Skaggerak. Ophelia 31, 191-207.

doi: http://dx.doi.org/10.1080/00785326.1991.10429695

Harmon JR, Thomas KL, McIntyre KW \& Paasch NN 1994. Prevalence of marine-mammal tooth and claw abrasions on adult anadromus salmonids returning to the Snake River. North American Journal of Fisheries management 14, 661-663. doi: http://dx.doi.org/10.1577/1548-

8675(1994)014<0661:POMMTA >2.3.CO;2

Hauksson E 1990. Skaðsemi sela fyrir laxveiðar og laxeldi. [The harmfullness of seals to salmon angling and salmon farming]. Veiðimaðurinn 46, 55-63. [In Icelandic].

Hauksson E 2005. Nematode infestation and diet of fish, cormorants (Phalacrocorax carbo) and common seals (Phoca vitulina) at Melrakkanes, Hamarsfjörður, Eastern Iceland. In: Erlingur Hauksson et al., Nematodes and diet of fish, cormorants and seals: Marine Research Institute. Report no. 115, 21-30. [Icelandic with English abstract]

Hauksson E 2010. Monitoring trends in the abundance of harbour seals (Phoca vitulina) in Icelandic waters. NAMMCO Scientific Publications 8, 227-244.

Hauksson E \& Bogason V 1997. Comparative Feeding of Grey (Halichoerus grypus) and Common Seals (Phoca vitulina) in Coastal Waters of Iceland, with a Note on the Diet of Hooded (Cystophora cristata) and Harp Seals (Phoca groenlandica). Journal of Northwest Atlantic Fishery Science 22, 125-135.

Jobling M 1987. Marine mammal faecal samples as indicators of prey importance - A source of errors in bioenergetics studies. Sarsia 72, 255-260. doi: http://dx.doi.org/10.1080/00364827.1987.10419722
Lilliendahl K, Hansen E, Bogason V, Sigursteinsson M, Magnúsdóttir M, Jónsson P \& Sigurðsson Ó 2013. Viðkomubrestur lunda og sandsílis við Vestmannaeyjar. [Low occurrence of puffin and sand eels in the Westman Islands, Iceland]. Náttúrurfrceðingurinn 83, 65-79 [In Icelandic].

Marine Research Institute 2011. State of Marine Stocks in Icelandic Waters 2010/2011. Prospects for the Quota year 2011/2012. Fjölrit 159, 180p. [In Icelandic, English summary].

Matejusová I, Doig F, Middlemas SJ, Mackay S, Douglas A, Armstrong JD, Cunningham, CO \& Snow M 2008. Using quantitative real-time PCR to detect salmonid prey in scats of grey Halichoerus grypus and harbour Phoca vitulina seals in Scotland-An experimental and field study. Journal of Applied Ecology 45, 632-640.

doi: http://dx.doi.org/10.1111/j.1365-2664.2007.01429.x

Middlemas SJ, Barton TR, Armstrong JD \& Thompson PM 2006. Functional and aggregative responses of harbour seals to changes in salmonid abundance. Proceedings of the Royal Society of London B: Biological Sciences 273, 193-198. doi: http://dx.doi.org/10.1098rspb.2005.3215

NAMMCO Annual Report 2014. North Atlantic Marine Mammal Commission, Tromsø, Norway, $247 \mathrm{p}$.

Naughton GP, Keefer ML, Clabough TS, Jepson MA, Lee SR, Peery CA \& Caudill CC 2011. Influence of pinniped-caused injuries on the survival of adult Chinook salmon (Oncorhynchus tshawytscha) and steelhead trout (Oncorhynchus mykiss) in the Columbia River basin. Canadian Journal of Aquatic Science 68, 1615-1624. doi: http://dx.doi.org/10.1139/f2011-064

Nebel SE 2011. The consumption of commercially valuable fish by pinnipeds in Northwest Icelandic waters. Master's thesis. University Centre of the West Fjords, Ísafjördur, University of Akureyri Faculty of Business and Science, May 2011, 68 pp.

Ólafsdóttir D \& Hauksson E 2005. Energy content of some fish and invertebrate species in Icelandic waters. Marine Research Institute. Fjölrit 115, 3945.

Pierce GJ \& Boyle PR 1991. A review of methods for diet analysis of piscivorous marine mammals. Oceanography and Marine Biology 29, 409-486. 
R Development Core Team 2009. R: a language and environment for statistical computing. Vienna, Austria: R Foundation for Statistical Computing. Accessed 03.10.2011 at http://www.R-project.org.

Roffe TJ \& Mate BR 1984. Abundances and feeding habits of pinnipeds in the Rogue River, Oregon. The Journal of Wildlife Management 48, 12621274. doi: http://dx.doi.org/10.2307/3801787

Silva J \& Neilson J 1985. Limitations of using otoliths recovered in scats to estimate prey consumption in seals. Canadian Journal of Fisheries and Aquatic Sciences 42, 1439-1442. doi: http://dx.doi.org/10.1139/f85-180

Svetocheva O, Stasenkova N \& Fooks G 2007. Guide to the Bony Fishes Otoliths of the White Sea. IMR/PIRNO Joint Report Series 3, 1502-8828

Thompson P \& Miller D 1990. Summer foraging activity and movements of radio-tagged common seals (Phoca vitulina L.) in the Morray firth Scotland. Journal of Applied Ecology 27, 492-501. doi: http://dx.doi.org/10.2307/2404296

Thompson PM \& Mackay F 1999. Pattern and prevalences of predator damage on adult Atlantic salmon, Salmo salar L., returning to a river system in north-east Scotland. Fisheries Management and Ecology 6, 335-343.

doi: http://dx.doi.org/10.1111/j.1365-2400.1999.

tb00084.x

Thompson PM, Mackey B, Barton TR, Duck C \& Butler JRA 2007. Assessing the potential impact of salmon fisheries management on the conservation status of harbour seals (Phoca vitulina) in northeast Scotland. Animal Conservation 10, 48-56.

doi: http://dx.doi.org/10.1111/j.1469-1795.2006.00066.x

Thórisson K \& Sturlaugsson J 1995. Postsmolt of ranched Atlantic salmon (Salmo salar L.) in Iceland: IV. Competitors and predators. International Concil for the Exploraton of the Sea. ICES C.M. 1995/M:12. 10p.

Toivonen AL, Roth E, Navrud S, Gudbergsson G, Appelblad H, Bengtsson B, \& Tuunainen P 2004. The economic value of recreational fisheries in Nordic countries. Fisheries Management and Ecology 11, 1-14.

doi: http://dx.doi.org/10.1046/j.1365-2400.2003.00376.x

Windell, J 1971. Food analysis and rate of digestion. In Ricker W \& Ricker W (eds). Methods for assessment of fish production in fresh waters (Second ed.). International Biological Programme by Blackwell Scientific Publ., Oxford, pp. 215-226.

Zamon JE 2001. Seal predation on salmon and forage fish schools as a function of tidal currents in the San Juan Islands, Washington, USA. Fisheries Oceanography 10, 353-366.

doi: http://dx.doi.org/10.1046/j.1365-2419.2001.00180.x

Manuscript received 12 February 2016

Accepted 31 March 2016 